readers that the report reoommends substituting bicycles for cars, and that it would "move more than $1,000,000$ people a year to new communities where they would work at the jobs planned for them by the government. The advertisement recommends elimination of energy waste (which it neglects to define), urges the development of new energy resources immediately and suggests that some environmental regulations should be relaxud. Without energy growth, Americans would "sacrifice their living standards", the advertisement implies.

Such sentiments can be found within the covers of the report itself, however. Before being published, the report was circulated to members of the Energy Policy Project's Advisory Board-a collection of individuals from industry, academe, environmental organisations and government-and their views appear as an appendix to the study. The nature of their criticisms is fairly well determined by who they represent.

Thus, Michael McClosky, Executive Director of the Sierra Club, takes the study to task for not recommending negative energy growth, and for being too timid in discussing the environmental consequences of high energy growth. Donald C. Burnham. Chairman of Westinghouse Electruc Corporation, disagrees with the suggestion that energy growth and economic growth can be uncoupled. The assertions to that end are "totally unsupported by the facts", he says, and the changes-proposed "would result in substantial social upheaval, as well as economic stagnation". But the most outspoken criticisms are offered by William P. Tavoulareas, President of Mobil, who says that the report is distorted and offers a recipe for economic disaster.

$\mathrm{Be}$ that as it may, will the study have any effect on government policy? The Administration's attitude towards energy conservation, as stated by $\mathrm{Mr}$ Ford in his economic message, is that it is clearly a good thing but that at this stage it should be voluntary. Mr Ford said that he hoped consumers and industry would be able to cut back enough to wipe a million barrels of oil a day off the import side of the trade ledger by 1976 and warned that some mandatory controls would have to be applied if voluntary conservation doesn't work. But he specifically rejected a recommrndation from his chief energy adviser that a $30 \%$ tax should be slipped on petrol, and Congress would be: extremely reluctant to take politically sensitive steps to allow energy prices to rise.

The over-riding policy remains as stated often by President Nixon-that domestic energy resources should be developed as rapidly as possible to offset oil importts.
IT was just a year ago that former President Nixon launched Project Independence with a rhetorical flourish and directed the Federal Energy Administration (FEA) to draw up a policy which will make the United States self-sufficient in energy supplies by 1980 . Called the Project Independence blueprint, the FEA's plan will be published early in November, but with Nixon's original timetable long ago declared impossible, it represents more a discussion of options than a blueprint for selfsufficiency.

According to conversations with several energy officials and Congressional sources, the study's chief message is that the United States will have to rely on imported oil to meet its energy demands for at least the next decade, and probably for long after that.

Unlike the Ford Foundation study, the FEA blueprint does not suggest that decisions on whether or not to develop controversial domestic energy resources can be put off for a decade, but it does nevertheless put forward some ideas for energy conservation.

First, however, the blueprint suggests that if energy prices remain at present inflated levels, this alone could depress demand and cause the growth in energy consumption in the United States to drop to about 3\% a year by 1985 . In addition, measures such as mandatory fuel economy standards for new cars, credits for

\section{Plans for two more Dutch satellites}

\section{from Arie de Kool, Rotterdam}

Even though the first Dutch satellite, ANS, did not achieve its intended orbit, both astronomers and technicians are in good spirits because the instrument nonetheless works well. This is supposed to prove that Philips and Fokker-VFW may now regard themselves as able space companies. Astronomers are busy reprogramming their computers to make full use of the new orbital parameters.

Such success deserves to be continued-reasons the Dutch National Institute for Aerospace Development, which was established to promote industrial activity in the field. So it proposes two further satellites, both bigger than ANS, and too large to be built within the present decade or launched by a Scout rocket.

'Phase A' preparatory studies and preliminary design studies have been completed for the first satellite, another one devoted to astronomy, in fact an advanced infrared telescope. insulating buildings and incentives for industry to use energy-saving technologies could bring the growth in consumption close to the $2 \%$ level recommended in the Ford Foundation study, the FEA reckons.

One reason why the United States is unlikely to stop importing oil in the near future, the study suggests, is that there is only a limited possibility for substituting some of the country's massive deposits of coal for oil. Such a substitution has been vigorously recommended both by former President Nixon and by President Ford, but the FEA analysis points out that only in electricity generation can coal replace oil to a large extent. Consequently, the study predicts that coal consumption will perhaps double by 1985 , where as most previous forecasts have suggested that production will be tripled during the next decade, and that oil imports will be needed to meet demand at least until 1985, even with extensive drilling off the Atlantic and Pacific coasts and in the Gulf of Alaska.

The FEA study has some cautionary things to say about strip mining for coal in the arid western regions, suggesting that it will be environmentally destructive and that the coal will in any case contain large quantities of uranium, which could prove to be a health hazard. Similarly, the study pours cold water on the prospects for exploration of oil shale.

The money is supposed to come from the Ministry of Economic Affairs and the Science Ministry. "After all, one should not expect that industry will be prepared to pay for a satellite it did not ask for", said one official of the Economy Department.

The second proposal is for an Earth resources satellite, with the principal objective of plant disease recognition. Most of the money for this one would have to come from the Department for Development Aid. "One of the main problems to be overcome is to convince the developing countries that they do have an interest in cooperation with a neutral country like Holland in this field", said the same government official.

A group of scientists has, however, taken issue with these propositions. They feel that other fields of science take priority over space research and they are particularly convinced that remote sensing techniques, if at all useful, can only serve the owners of large monoculture plantations, not the small farmers who should, they say, be considered as the backbone of the developing countries. 